\title{
Penegakan Hukum Persidangan Cepat Dalam Penyelesaian Perkara Pelanggaran Lalu Lintas (Studi Satlantas Polrestabes Medan)
}

\section{Law Enforcement A Speedy Trial in The Settlement of a Traffic Violation (The Regional Police Departemen Study)}

\author{
Foni Mega Wahyuni*, Triono Eddy \& Alpi Sahari
}

\author{
Program Magister Ilmu Hukum, Universitas Muhammadiyah Sumatera Utara, Indonesia \\ Diterima: Juni 2020; Disetujui: Agustus 2020; Dipublish: Agustus 2020 \\ *Email: fonimega33@gmail.com
}

\begin{abstract}
Abstrak
Pelanggaran lalu lintas dalam Undang-Undang Hukum Acara Pidana (KUHAP) dikelompokkan bersama dengan tindak pidana ringan untuk mengikuti prosedur pemeriksaan acara cepat. Metode dalam penelitian ini berjenis penelitian hukum yuridis empiris, yaitu suatu penelitian yang melakukan kajian terhadap penelitian di lapangan, dilakukan penelitian langsung (risearch) mengenai penegakan hukum persidangan cepat dalam penyelesaian perkara pelanggaran lalu lintas. Penelitian ini menggunakan metode pendekatan kualitatif. Berasarkan penelitian ditemukan beberapa kendala dalam penegakan hukum persidangan cepat dalam penyelesaian pelanggaran lalu lintas antara lain: Pertama, banyaknya pelanggaran lalu lintas di Kota Medan yang membuat Hakim yang menyidangkan akan kewalahan, ditambah dengan pasilitas-pasilitas ruangan yang kurang luas atau sarana prasarana yang kurang mendukung yang akan membuat ruangan akan dipenuhi oleh para pelanggar lalu lintas yang akan bersidang diruangan Pengadilan. Kedua, dalam proses persidangan acara cepat masih banyak para pelanggar lalu lintas yang menggunakan calo dalam proses penegakan hukumnya, dikarenakan keramaian para petugas pengadilan terkadang sulit membedakan mana calo yang sering bermain dalam pengurusan proses penegakan hukum.
\end{abstract}

Kata Kunci: Penegakan, Persidangan, Pelanggaran Lalu Lintas

\begin{abstract}
Traffic violations in the Criminal Procedure Act (KUHAP) are grouped together with minor criminal offenses to follow the procedure for examining fast events. The method in this research is empirical juridical legal research type, which is a study that conducts a study of research in the field, conducted a direct research (risearch) regarding the enforcement of court proceedings quickly in the settlement of traffic violation cases. This research uses a qualitative approach. Based on the research, it was found that there were several obstacles in enforcing fast trial law in the settlement of traffic violations, among others: First, the number of traffic violations in Medan City which made the Judges who heard would be overwhelmed, coupled with less extensive room facilities or inadequate infrastructure facilities. which will make the room will be filled with traffic violators who will sit in the courtroom. Second, in the trial process of fast events there are still many traffic violators who use brokers in their law enforcement processes, because the crowds of court officials sometimes find it difficult to distinguish which brokers often play in the maintenance of the law enforcement process.
\end{abstract}

Keywords: Enforcement, Trials, Traffic Violations

How to Cite: Wahyuni, F.M., Eddy, T. \& Sahari, A. (2020). Penegakan Hukum Persidangan Cepat Dalam Penyelesaian Perkara Pelanggaran Lalu Lintas (Studi Satlantas Polrestabes Medan). Journal of Education, Humaniora and Social Sciences (JEHSS). 3(1): 85-90. 


\section{PENDAHULUAN}

Negara Indonesia adalah negara hukum, pengertian negara hukum secara sederhana adalah negara yang menyelenggarakan kekuasaan pemerintahannya berdasarkan hukum, dalam Pasal 3 Ayat (1) Undang-Undang Dasar Tahun 1945 disebutkan bahwa "Negara Indonesia adalah negara hukum", selanjutnya dalam penjelasan Undang-Undang Dasar Tahun 1945 disebutkan bahwa "negara Indonesia berdasarkan atas hukum (rechtstaat) tidak berdasarkan kekuasaan belaka (machstaat), oleh karena itu Negara tidak boleh melaksanakan aktivitasnya atas dasar kekuasaan belaka, tetapi harus berdasarkan pada hukum (C.S.T Kansil \& Christine, 2002).

Sebagai dasar legalitas Undang-Undang Nomor 22 Tahun 2009 tentang Lalu Lintas dan Angkutan Jalan (UU LLAJ) merupakan suatu aturan yang mengatur para pengendara bermotor dalam berkendara di jalan raya. Salah satu isi dari Undang-Undang Nomor 22 Tahun 2009 tentang Lalu Lintas dan Angkutan Jalan tersebut adalah bahwa setiap pengendara yang mengendarai kendaraan bermotor di jalan raya harus dilengkapi dengan Surat Izin Mengemudi (SIM), dimana kemampuan dari setiap pengendara didasarkan pada usia yang cukup yaitu minimal 17 tahun, serta keterampilan dalam hal menggunakan kendaraan bermotor. Surat Izin Mengemudi (SIM) ini dapat diperoleh jika telah lulus ujian teori dan praktik, tentunya dengan terpenuhinya persyaratan administratif yaitu fotokopi Kartu Tanda Penduduk (KTP), mengisi formulir, tanda tangan, sidik jari, dan foto serta membuat surat keterangan sehat jasmani dan rohani.

Permasalahan lalu lintas sangat sering menimbulkan banyaknya problem dalam masyarakat, diantaranya banyaknya pelanggaran-pelanggaran yang dapat kita temui dalam kehidupan kita sehari-hari, mulai dari pelanggaran rambu-rambu lalu lintas sampai dengan aturan yang ada, sehingga dapat menganggu ketertiban dalam masyarakat, khususnya terkait masalah penggunaan alat transportasi. Penyebabnya terdapat pada faktor-faktor seperti pengemudi maupun pemakai jalan yang lainnya, konstruksi jalan yang kurang baik, kendaraan yang tidak memenuhi syarat, rambu-rambu lalu lintas yang tidak jelas, dan lain sebagainya. Misalnya jalan raya yang merupakan suatu sarana bagi manusia untuk mengadakan hubungan antar tempat, dengan mempergunakan berbagai jenis kendaraan baik yang bermotor maupun tidak. Jalan raya mempunyai peranan penting dalam bidang ekonomi, politik, sosial budaya, pertahanan, keamanan dan hukum, serta dalam hal menggunakan kendaraan bermotor. Surat Izin Mengemudi (SIM) ini dapat diperoleh jika telah lulus ujian teori dan praktik, tentunya dengan terpenuhinya persyaratan administratif yaitu fotokopi Kartu Tanda Penduduk (KTP), mengisi formulir, tanda tangan, sidik jari, dan foto serta membuat surat keterangan sehat jasmani dan rohani.

Permasalahan lalu lintas sangat sering menimbulkan banyaknya problem dalam masyarakat, diantaranya banyaknya pelanggaran-pelanggaran yang dapat kita temui dalam kehidupan kita sehari-hari, mulai dari pelanggaran rambu-rambu lalu lintas sampai dengan aturan yang ada, sehingga dapat menganggu ketertiban dalam masyarakat, khususnya terkait masalah penggunaan alat transportasi. Penyebabnya terdapat pada faktor-faktor seperti pengemudi maupun pemakai jalan yang lainnya, konstruksi jalan yang kurang baik, kendaraan yang tidak memenuhi syarat, rambu-rambu lalu lintas yang tidak jelas, dan lain sebagainya. Misalnya jalan raya yang merupakan suatu sarana bagi manusia untuk mengadakan hubungan antar tempat, dengan mempergunakan berbagai jenis kendaraan baik yang bermotor maupun tidak. Jalan raya mempunyai peranan penting dalam bidang ekonomi, politik, sosial budaya, pertahanan, keamanan dan hukum, serta dipergunakan untuk sebesar-besarnya kemakmuran rakyat.

Aparat penegak hukum dalam hal ini Polisi Lalu Lintas berperan sebagai pencegah (politie toezicht) dan sebagai penindak (politie dwang) dalam fungsi politik. Polisi lalu lintas juga melakukan fungsi regeling yaitu pengaturan tentang kewajiban bagi kendaraan bermotor tertentu untuk melengkapi dengan segitiga pengaman dan fungsi bestuur khususnya dalam hal perizinan atau begunstiging yakni mengeluarkan Surat Izin Mengemudi (Soekanto, 1989).

Pelanggaran lalu lintas ini tidak diatur pada KUHP akan tetapi ada yang menyangkut delikdelik yang disebut dalam KUHP, misalnya Pasal 359, dalam kealpaannya menyebabkan matinya orang, Pasal 360, karena kealpaanya meyebabkan orang lain luka berat, Pasal 409, karena kealpaannya menyebabkan bangunan bangunan, trem kereta api, telegram, telepon, dan listrik sebagainya hancur atau rusak, (Moeljanto, 2008). 
Menurut ketentuan KUHAP ada tiga acara pemeriksaan di dalam menyelesaikan perkara pidana yakni: Acara Pemeriksaan Biasa, Acara Pemeriksaan Singkat dan Acara Pemeriksaan Cepat. Ketiga acara Pemeriksaan tersebut dijalankan berdasarkan bentuk corak perkara yang diterimannya, sehingga apabila jenis perkara yang diterimannya adalah perkara biasa maka harus pula diselesaikan dengan mengunakan acara pemeriksaan biasa, jika yang diterima itu jenis perkara berdasarkan pasal 203 KUHAP, maka acara yang digunakan adalah Acara Pemeriksaan Singkat. Namun jika perkara itu adalah perkara yang diancam dengan pidana penjara atau kurungan paling lama tiga bulan dan atau denda sebanyak-banyaknya tujuh ribu lima ratus rupiah dan penghinaan ringan serta perkara pelanggaran lalu lintas jalan, maka perkara tersebut harus diselesaikan dengan acara pemeriksaan cepat (Ali, 2012).

Penjelasan mengenai pengertian pelanggaran lalu lintas, maka perlu dijelaskan lebih dahulu mengenai pengertian pelanggaran itu sendiri dan pengertian pelanggaran yang dikemukakan oleh beberapa sarjana hukum. Dalam KUHP membagi tindak pidana atas kejahatan (misdrijve) dan pelanggaran (overtredingen). Mengenai kejahatan itu sendiri dalam KUHP diatur dalam buku II yaitu tentang kejahatan. Sedangkan pelanggaran diatur dalam dalam buku III yaitu tentamg pelanggaran. Dalam ilmu pengetahuan hukum pidana terdapat dua pandangan mengenai kriteria pembagian tindak pidana, 21 kejahatan dan pelanggaran, yaitu yang bersifat kualitatif dan yang bersifat kuantitatif (Rusli, 2013).

Acara pemeriksaan cepat yang diatur dalam Kitab Undang-Undang Hukum Acara Pidana meliputi acara pemeriksaan tindak pidana ringan dan perkara pelanggaran lalu lintas. Pasal 211 KUHAP disebutkan bahwa yang diperiksa menurut acara pemeriksaan pelanggaran lalu lintas adalah pelanggaran lalu lintas tertentu terhadap peraturan perundang-undangan lalu lintas (Dahlan, dkk., 2013; Siregar, dkk., 2019; Yudianto, dkk., 2010).

Untuk menemukan pemahaman yang tepat tentang penyelesaian perkara pelanggaran lalu lintas berkaitan dengan peradilan dengan acara cepat berkaiatan dengan penegakan hukum pelanggaran lalu lintas, maka dilakukan penelitian tesis dengan judul "Penegakan Hukum Persidangan Cepat Dalam Penyelesaian Perkara Pelanggaran Lalu Lintas (Studi di Satlantas Polrestabes Medan)".

\section{METODE PENELITIAN}

Jenis penelitian dalam penulisan ini bersifat deskriptif analisis dengan jenis penelitian hukum normatif. Sumber data penelitian dari bahan hukum primer, yaitu Undang-Undang Nomor 22 Tahun 2009 tentang Lalu Lintas dan Angkutan Jalan, Peraturan Mahkamah Agung RI No. 1 Tahun 2014 tentang Pedoman Pemberian Layanan Hukum bagi Masyarakat Tidak Mampu, Kitab Undang-Undang Hukum Pidana (KUHP), Kitab Undang-Undang Hukum Acara Pidana (KUHAP). Bahan hukum sekunder dan bahan hukum tersier.

Pengumpulan data yang digunakan studi kepustakan (library research) di Satlantas Polrestabes Medan dengan alat pengumpulan data studi dokumen. Penarikan kesimpulan dalam tulisan ini dilakukan dengan menggunakan logika berfikir deduktif-induktif yaitu dilakukan dengan teori yang digunakan sebagai titik tolak untuk melakukan penelitian. Dengan demikian teori digunakan sebagai alat, ukuran dan intrumen atau sebagai pisau analisis dalam melihat permasalahan terhadap sidang ditempat terhadap pelanggaran lalu lintas.

\section{HASIL DAN PEMBAHASAN}

\section{Proses Penegakan Hukum Persidangan Cepat Dalam Penyelesaian Perkara Pelanggaran Lalu Lintas di Satlantas Polrestabes Medan}

Penegakan hukum tentang pelanggaran lalu lintas, ada beberapa Peraturan PerundangUndangan yang megatur sebagai berikut : a. Paragraf 2 Bagian Keenam Bab XVI, Pasal 211-216 KUHAP; b. Undang-Undang No.14 Tahun 1992 tentang Lalu Lintas dan Angkutan Jalan, sebagaimana telah diubah dengan Undang-Undang No. 22 tahun 2009; c. Peraturan Pemerintah No. 41 Tahun 1993 tentang Angkutan Jalan; d. Peraturan Pemerintah No.42 Tahun 1993 tentang Pemeriksaan Kendaraan di Jalan; e. Peraturan Pemerintah No. 43 Tahun 1993 tentang Prasarana dan Lalu lintas Jalan; f. Peraturan Pemerintah No. 44 Tahun 1993 tentang Kendaraan dan 
Vol 3, No. 1, Agustus 2020: 85 -90,

Pengemudi; g. SEMA No.22 Tahun 1983 tentang pidana denda dalam perkara cepat harus segera dilunasi; h. SEMA No. 3 Tahun 1989 tentang pidana kurungan dalam perkara lalu lintas; i. SEMA No. 4 Tahun 1993 tentang petunjuk pelaksanaan tata cara penyelesaian perkara pelanggaran lalu lintas jalan tertentu;

Aparat penegak hukum dapat dimaksudkan sebagai corongnya undang-undang yang diberi tugas untuk menegakkan hukum ditengah-tengah masyarakat, dangan artian lain jika kinerja aparat penegak hukum lemah maka sudah dapat dipastikan semua aturan perundang-undangan akan menjadi lembaran kertas yang tidak ada artinya (Banit Pendidikan Rekayasa Satlantas Polrestabes Medan:2019).

Setiap aparat dan aparatur terkait mencakup pula pihak-pihak yang bersangkutan dengan pula pihak-pihak yang bersangkutan dengan tugas atau perannya yaitu terkait dengan kegiatan pelaporan atau pengaduan, penyelidikan, penyidikan, penuntutan, pembuktian, penjatuhan vonis dan pemberian sanksi serta upaya pemasyarakatan kembali (resolisasi) terpidana. Dalam proses bekerjanya hukum itu setidaknya terdapat 3 (tiga) elemen penting yang mempengaruhi yakni: 1) Institusi penegak hukum beserta dalam berbagai perangkat perangkat sarana dan prasarana pendukung dan mekanisme kerja kelembagaan. 2) Budaya kerja yang terkait dengan aparatya, termasuk mengenai kesejahteraan aparatnya. 3) Perangkat peraturan yang mendukung baik kinerja kelembagaanya maupun yang mengatur materi hukum yang dijadikan standar kerja, baik hukum materilnya maupun hukum acaranya (Peter Mahmud Marzuki: 2008).

Penanggulangan terhadap pelaku pelanggaran lalu lintas Satlantas Polres Medan melakukan hal berikut: 1) Pendekatan Pre-emtif yakni upaya-upaya awal yang dilakukan oleh pihak kepolisian untuk mencegah terjadinya pelanggaran lalu lintas khususnya dalam hal modifikasi kendaraan. 2) Pendekataan Preventif dengan bentuk pencegahan kecelakaan lalu lintas dengan cara pengaturan, penjagaan, pengawalan, dan patroli yang dilaksanakan dengan optimalisasi peran anggota satuan lalu lintas. 3) Pendekatan Represif dengan cara Operasi Rutin dan Operasi Gabungan (Banit Pendekatan Rekayasa Satlantas Polrestabes Medan: 2019).

Penegakan hukum lalu lintas terhadap pelanggaran lalu lintas menggunakn hukum acara pemeriksaan cepat dalam Pasal 211 KUHAP. Dari penjelasan mengenai ketentuan yang diatur dalam Pasal 211 KUHAP ini dapat diketahui, bahwa yang dimaksud dengan perkara pelanggaran tertentu itu adalah (Samapto, 2009).

1. Mempergunakan jalan dengan cara yang dapat merintangi, membahayakan keteritiban atau keamanan lalu lintas atau yang mungkin menimbulkan kerusakan pada jalan.

2. Mengemudikan kendaraan bermotor yang tidak dapat memperlihatkan surat izin mengemudi (SIM), surat tanda nomor kendaraan, surat tanda uji kendaraan yang sah atau tanda bukti lainnya yang diwajibkan menurut ketentuan perundang-undangan lalu lintas jalan atau ia dapat memperlihatkannya tetapi masa berlakunya sudah kadaluarsa.

3. Membiarkan atau memperkenankan kendaraan bermotor dikemudikan orang yang tidak memiliki surat izin mengemudi

4. Tidak memenuhi ketentuan peraturan perundang-undangan lalu lintas jalan tentang penomoran, penereangan, peralatan, perlengkapan, pemuatan kendaraan dan syarat penggadungan dengan kendaraan lain.

5. Membiarkan kendaraan bermotor yang ada dijalan tanpa dilengkapi plat tanda nomor kendaraan yang bersangkutan. Pelanggran terhadap perintah yang diberikan oleh petugas pengatur lalu lintas jalan, dan isyarat pengatur lalu lintas jalan, rambu-rambu atau tanda yang ada dipergunakan jalan.

6. Pelanggaran terhadap ketentuan tentang ukuran dan muatan yang diizinkan, cara menaikkan dan menurunkan penumpang dan atau cara memuat dan membongkar barang.

7. Pelaggaran terhadap izin trayek, jenis kendaraan yang diperbolehkan beroperasi di jalan yang ditentukan .

Proses pemeriksaan persidangan secara cepat dalam perkara pelanggaran lalu lintas di pengadilan adalah: Sidang dipimpin oelh Hakim tunggal dan tebuka untuk umum tanpa kehadiran Jaksa, terdakwa dianggil dan diperiksa identitasnya. Menjelasakan perbuatan tindakan pidana yang didakwakan kepada terdakwa dan Hakim memperhatikan barang bukti berupa SIM, STNK

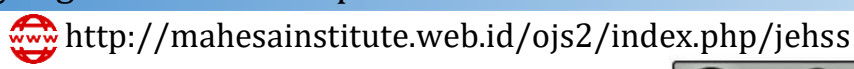
(1)mahesainstitut@gmail.com 88 
atau ranmor dan menanyakannya kepada terdakwa. Setelah itu Hakim memberitahukan ancaman pidana atas tindak pidana yang didakwakan kepada terdakwa. Hakim juga memberikan kesempatan kepada terdakwa untuk untuk mengajukan permohonan/pembelaan sebelum menjatuhkan putusan. Putusan dijatuhkan berupa pidana denda atau kurunngan yang besarnya ditetapkan pada hari sidang dihari itu juga, jika dihukum denda, maka harus dibayar seketika itu juga disertai pembayaran biaya perkara yang langsung dapat diterima oleh petugas yang mewakili kejaksaan sebagai eksekutor. Karena sesuai dengan Pasal 1 butir 6, Pasal 215, dan 270 KUHAP, pelaksanaan putusan dilaksanakan oleh Jaksa.

Pengembalian barang bukti dalam sidang acara cepat dapat dilakukan dalam sidang oleh hakim seketika setelah diucapkan putusan setelah pidana denda dan ongkos perkara dilunasi/dibayar. Semua denda maupun ongkos perkara yang telah diputuskan oleh Hakim seluruhnya wajib segera disetorkan ke kas Negara oleh Kejaksaan selaku eksekutor.

\section{Kendala dan Solusi Persidangan Secara Cepat Daalam Penyelesain Perkara Pelanggaran Lalu Lintas di Satlantas Polrestabes Medan}

Personil Satlantas Polres Medan memiliki kesadaran hukumnya masih rendah dan merasa bangga melakukan pelanggaran hukum sampai menjadi budaya masyarakat Indonesia dari generasi kegenerasi (Banit Pendekatan Rekayasa Satlantas Polrestabes Medan: 2019). Hal ini terlihat dari jumlah kasus selama Operasi Zebra Tahun 2016, 2017, 2018 dan 2019 Satlantas Polres Medan menindak 1.218 kasus kecelakaan lalu lintas, yang didominasi kendaraan roda dua dan empat, 148 orang dinyatakan meninggal dunia karena kecelakaan dan 470 orang mengalami luka berat.

Kendala yang menjadi faktor penghambat penegakan hukum lalu lintas dapat berasal dari dirinya sendiri dan lingkungan, faktor tersebut juga dapat berupa: a. Besarnya denda terhadap pengemudi sampai mencapai 3-4 kali lipat dari besarnya denda atau damai, b. prosedur hukum dipandang tidak sederhana, c. kurangnya kesadaran budaya taat hukum berlalu lintas dan mengabaikan keselamatan.

Hambatan lain dalam melakukan penanggulangan pelanggaran syarat teknis dan layak jalan pengemudi sepeda motor di Medan ialah jumlah personil yang kurang memadai, belum maksimalnya kegiatan pre-mtif serta kurangnya alat peraga dalam kegiatan Polisi Sahabat Anak.

Kendala dalam penegakan hukum persidangan secara cepat dalam perkara pelanggaran lalu lintas di Pengadilan Negeri Medan dapat di uraian sebagai berikut :1) Kendala banyaknya pelanggaran lalu lintas dan kurangnya hakim, 2) Kurangnya kesadaran hukum masyarakat.

Solusi atau upaya penanganan penegakan hukum terhadap masalah lalu lintas dapat diuraikan berikut: a) Partisipasi antara masyarakat dan aparat kepolisian harus bekerja sama memberikan edukasi dalam kaitan upaya penaggulangan dan pemberantasan kasus pelanggaran lalu lintas, b) Sosialisasi pihak kepolisian kepada masyarakat dalam bentuk pengadaan acara-acara terkait aturan dan larangan di jalan dalam hal mencapai keamanan dan rasa percaya masyarakat kepada pihak kepolisian dalam melaksanakan upaya penanggulangan dan pemberantasan pelanggaran yang terjadi di lapangan, c) melakuakan analisis dan pendekatan sosialisasi terhadap perusahaan kendaraan.

Berdasarkan seluruh rangkaian pembahasan mengenai Penegakan Hukum Pelanggaran Lalu Lintas, seperti yang telah diuraikan dalam pembahasan sebelumnya dapat di tarik kesimpulan dari uraian tersebut guna menjawab permasalahan adalah bahwa gagasan model alternatif penyelesaian pelanggaran lalu lintas bisa dilakukan secara sederhana, cepat dan murah serta tidak berbelit-belit seperti yang saat ini ada terlalu panjang sehingga membuat pelanggar lalu lintas mengambil jalan pintas dengan petugas. Gagasan model penyelesaian tilang baru ini dimana SIM dan STNK tidak disita oleh petugas akan tetapi Kartu Tanda Penduduk yang di sita karena jika dalam waktu jangka tertentu si pelanggar tidak membayar denda maka petugas bisa datang ke rumah pelanggar ataupun menanyakan melalui surat kepada si pelanggar.

Data jenis kendaraan dan pelanggar kendaraan bermotor didata oleh petugas kemudian data tersebut diteruskan ke Pengadilan maupun Kejaksaan. Menggunakan jaringan komputerisasi dan 
Vol 3, No. 1, Agustus 2020: 85 -90,

bekerja sama dengan bank, pelanggar cukup membayar tilang melalui ATM, internet banking bahkan sms banking.

Pelanggar yang telah membayar denda tilang lewat bank tersebut kemudian pihak bank meneruskan data tersebut ke kepolisian sub direktorat lalu lintas, pengadilan dan kejaksaan, akan tetapi jika dalam batas waktu tertentu pelanggar tidak membayar denda yang telah di tetapkan, kepolisian akan melakukan pemblokiran nomor kendaraan tersebut, sanksi yang lebih tegas jika dalam waktu tertentu denda tilang belum juga dibayar tapi yang bersangkutan kembali melanggar maka pihak kepolisian dapat melakukan penyitaan kendaraan tersebut.

Penyelesaian pelanggaran lalu lintas dalam bentuk tilang yang ada sekarang ini terdiri dari 3 (tiga) opsi yaitu; pelanggar langsung datang ke pengadilan, pelanggar membayar langsung lewat Bank BRI, menitipkan kuasa untuk sidang (petugas polantas).

\section{SIMPULAN}

Adapun yang menjadi simpulan dalam penulisan ini adalah bahwa acara pemeriksaan pelanggaran lalu lintas berlaku ketentuan hukum sebagaimana diatur dalam Pasal 211 sampai 216 KUHAP. Setiap pelanggaran di bidang lalu lintas dan angkutan jalan yang diperiksa menurut acara pemeriksaan cepat dapat di kenai pidana denda berdasarkan penetapan pengadilan. Melakukan pendekatan pre-emtif, preventif dan represif. Kendala dominan terhadap hambatan penegakan hukum lalu lintas ialah faktor kurangnya kesadaran hukum masyarakat. Solusi dan pencegahannya ialah melakuakan edukasi dan sosialisasi aparat dengan masyarakat.

\section{DAFTAR PUSTAKA}

Christine S.T. Kansil, C.S.T Kansil. (2002). Hukum dan Tata Negara Republik Indonesia Cetakan Ketiga. Rineka Cipta. Jakarta. halaman 90.

Dahlan, M., dan Marlina, (2013), Analisis Putusan Hakim Terhadap Tindak Pidana Lalu Lintas yang Menyebabkan Kematian (Studi Putusan di Pengadilan Negeri Sigli), Mercatoria, 6 (1): 104-116

Harahap M.Y. (2010). Pembahasan Permasalahan dan Penerapan KUHAP. Cetakan ke 12. Sinar Grafika.

Mahrus, A. (2012). Dasar-Dasar Hukum Pidana. Jakarta: Sinar Grafika.

Moeljatno, (2008). Asas-Asas Hukum Pidana. Jakarta: Rieneka Cipta

Rusli. M. (2013). Lembaga Pengadilan Indonesia Beserta Putusan Kontroversial, UII Pres, Yongyakarta.

Samapto, S.A., (2009). Penyelesaian Perkara Pidana di Luar Pengadilan Terhadap Dugaan Kejahatan Pasal 359 KUHP Dalam Perkara Lalu Lintas, STMIK AMIKOM. Yongyakarta.

Siregar, R.D.W, Mubarak, R \& Zulyadi, R. (2019). Peranan Kepolisian Dalam Penerapan Restorative Justice Terhadap Kecelakaan Lalu Lintas Di Wilayah Polsek Deli Tua (Studi Kasus Polsek Delitua). JUNCTO, 1(2) 2019: 150-157,

Soekanto, S. (1989). Suatu Tinjauan Sosiologi Hukum Terhadap Masalah-masalah Sosial, Bandung : Citra Aditya Bakti. Halaman 58

Yudianto, E., Marlina, dan Arif, (2010), Peran Kepolisian Republik Indonesia dalam Sosialisasi UndangUndang Nomor 22 Tahun 2009 tentang Lalu Lintas dan Angkutan Jalan (Studi pada Markas Kepolisian Daerah Sumatera Utara), Mercatoria, 3 (1): 20 - 33.

Kitab Undang-Undang Hukum Acara Pidana

Kitab Undang-Undang Hukum Pidana

Undang-Undang Dasar Negara Republik Indonesia Tahun 1945

Undang-Undang No. 14 Tahun 1992 tentang Lalu Lintas dan Angkutan Jalan, sebagaimana telah diubah dengan Undang-Undang No. 22 tahun 2009 